\title{
Determination of planting spacing for improved yield and yield components of Dekoko (Pisum sativum var. abyssinicum) at Raya Valley, Northern Ethiopia
}

\author{
Berhane Sibhatu $^{1 *}$, Hayelom Berhe ${ }^{2}$, Gebremeskel Gebrekorkos $^{1}$ and Kasaye Abera ${ }^{1}$ \\ ${ }^{1}$ Department of Agronomy, Ethiopian Institute of Agricultural Research, Mehoni Agricultural Research Center, \\ P.O. Box, 71, Maichew, Ethiopia. \\ ${ }^{2}$ Land and Water Research Process, Ethiopian Institute of Agricultural Research, Mehoni Agricultural Research Center, \\ P.O. Box, 71, Maichew, Ethiopia.
}

Received 14 May, 2016; Accepted 28 June, 2016

\begin{abstract}
Dekoko is a cool-season food legume cultivated in Tigray, Northern Ethiopia. It is highly appreciated by the local people for its taste and high market value. Yields of Dekoko, however, are limited by improper planting spacing. Thus, an experiment was conducted in 2013 and 2014 cropping seasons to determine the appropriate planting spacing of Dekoko that maximizes its productivity under rain fed conditions. Treatments comprised combinations of three plant spacing $(10,15$ and $20 \mathrm{~cm})$ and three levels of row spacing $(40,50$ and $60 \mathrm{~cm})$ and broad casting were done in a randomized complete block design with three replications. Plant spacing influenced plant height, grain yield and biomass yield. The greatest plant height $(50.63 \mathrm{~cm})$ was obtained at a spacing of $60 \times 20 \mathrm{~cm}$ while the maximum mean grain $(544.58$ $\mathrm{kg} \mathrm{ha}^{-1}$ ) and biomass yields ( $1562.65 \mathrm{~kg} \mathrm{ha}^{-1}$ ) were obtained at spacing of $40 \times 15 \mathrm{~cm}$ in both cropping seasons. A planting spacing of $40 \times 15 \mathrm{~cm}$ is recommended for the growers in the study area.
\end{abstract}

Key words: Dekoko, plant spacing, row spacing, yield, yield components.

\section{INTRODUCTION}

Ethiopia is the largest producer of cool-season food legumes (CSFLs) in Africa. The CSFLs are largely produced by subsistence farmers and serve as supplementary protein sources and soil fertility restorers. Among the CSFLs, a pea variety locally called Dekoko (Pisum sativum var. abyssinicum) is a unique crop developed and cultivated in Ethiopia (Haddis et al., 2015). It is restricted to highland regions of Ethiopia
(South Tigray and North Wollo) (Yemane and Skjelvag, 2002).

Dekoko is well appreciated for its taste and obtains a premium price in local markets as compared to field pea or 'Ater' (Pisum sativum var. sativum) (Yemane and Skjelvag, 2002). Farmers and consumers call it the "Dero-Wot of the poor". This may be due to its good taste and high nutritional value. Most often, the dry seeds of

*Corresponding author. E-mail: berhane76@gmail.com.

Author(s) agree that this article remains permanently open access under the terms of the Creative Commons Attribution License 4.0 International License 
Dekoko are decorticated and split ('split peas') before boiling. According to Sentayehu (2009), in Ethiopia, the annual consumption per person of field pea including Dekoko seeds is estimated at $6-7 \mathrm{~kg}$. Both field pea and Dekoko are considered as protein supplement in the cereal based diets of Ethiopia. The work of Yemane and Skjelvag (2002) showed that due to its favorable amino acid profile, it can be a suitable complementary protein source for a cereal based diet. Moreover, its early maturation can make it an important crop in areas where the growing season is too short for other CSFLs and yield losses caused by terminal droughts are common. The CSFLs are soil fertility restorers for subsistence farmers in Ethiopia (Yemane and Skjelvag, 2002).

Optimum plant population has a promising impact in improving the productivity of legumes. According to Pawar et al. (2007), dry weight of green bean was increased with increased row spacing $(30 \mathrm{~cm})$ as compared to narrow row spacing $(22.5 \mathrm{~cm})$. Wider row spacing (60 and $45 \mathrm{~cm}$ ) gave significantly higher number of pods plant $^{-1}$ as compared to $30 \mathrm{~cm}$ row spacing (Mohammed et al., 1984). This is supported by Kakiuchi and Kobata (2004) who concluded that lower plant density increased the pod number plant ${ }^{-1}$ and the higher plant density, decreased the pod number plant ${ }^{-1}$. Samih (2008) reported that high yield was observed in the case of high plant populations $(20 \times 30 \mathrm{~cm})$ over that of low plant population $(60 \times 30 \mathrm{~cm})$ of bush beans. Similarly, Gan et al. (2007) have shown increase of grain yield at higher plant density in chickpea. The use of high plant density usually increases seed yield of chickpea in areas with a short growing season (Gan et al., 2003), but the magnitude of the yield increase depends on environmental conditions. However, Parihar (1996) indicated that row spacing had no significant effect on seed yield. Other studies by Nawaz et al. (1995) and Felton et al. (1996) concluded that dry matter production and plant height of chick pea were higher in higher plant populations $(60$ plants $\mathrm{m}^{-2}$ ), but a population of 40 plants $\mathrm{m}^{-2}$ gave the maximum grain yield.

Dekoko is the most neglected pulse crop in the Tigray Region. Research has not yet been done on improved management practices for yield improvement of Dekoko. Productivity is low because of lack of improved varieties, low soil fertility, little or no application of fertilizers, insect pests and lack of improved agronomic practices including seeding rate and row spacing.

An experiment was conducted on planting spacing of Dekoko in Raya Valley, Northern Ethiopia. The objective of this study was to identify the optimal planting spacing of Dekoko under rain fed conditions.

\section{MATERIALS AND METHODS}

\section{Description of the experimental area}

The experiment was carried out under rain fed conditions in 2013 and 2014 cropping seasons at Mehoni Agricultural Research
Center testing site $\left(12^{\circ} 41^{\prime} 50^{\prime \prime} \mathrm{N}\right.$ and longitudes of $\left.39^{\circ} 42^{\prime} 08^{\prime \prime} \mathrm{E}\right)$. It is $678 \mathrm{~km}$ north of Addis Ababa. The area is situated at an altitude of $1578 \mathrm{~m}$ above sea level (m.a.s.l) with mean annual rainfall of 750 $\mathrm{mm}$ and minimum and maximum annual temperature is 18 and $25^{\circ} \mathrm{C}$, respectively. The textural class of the soil was clay loam with a $\mathrm{pH}$ value of 7.9 at a soil depth of $0-30 \mathrm{~cm}$ (Haileslassie et al., 2015).

\section{Treatments and experimental procedures}

The experiment consists of combinations of three intra row spacing $(10,15$ and $20 \mathrm{~cm})$ and three inter row spacing $(40,50$ and $60 \mathrm{~cm})$, and a broad casting planting pattern. The treatments were arranged in a randomized completed block design (RCBD) with three replications having a plot size of $6 \times 5 \mathrm{~m}$. The spacing between blocks and plots was 1.5 and $0.5 \mathrm{~m}$, respectively. Urea and triple super phosphate (TSP) were used as source of $\mathrm{N}$ and $\mathrm{P}$, respectively. $20 \mathrm{~kg} \mathrm{P}^{-1}$ in the form of $\mathrm{P}_{2} \mathrm{O}_{5}$ was applied at planting as band for row planting and broad casted application for broad casting method of planting. Similarly, $23 \mathrm{~kg} \mathrm{ha}^{-1}$ of $\mathrm{N}$ was applied as a starter at planting. Local variety of Dekoko was used as a test crop. The other crop management practices like weeding (first weeding was done three weeks after planting and second weeding was six weeks after planting), thinning and chemical spraying were applied uniformly to all plots as per recommendations in field pea.

\section{Data collection and statistical analysis}

Data on days to $90 \%$ maturity, plant height $(\mathrm{cm})$, pod number plant ${ }^{1}$, seed number pod ${ }^{-1}$, grain yield $\left(\mathrm{kg} \mathrm{ha}^{-1}\right)$, biomass yield $\left(\mathrm{kg} \mathrm{ha}^{-1}\right)$ were collected and analyzed. The data were collected from middle rows of a net plot area where the two outer most rows of each treatment were left as border effects. In addition, $0.10,0.15$ and 0.20 m length in both ends for 10,15 and $20 \mathrm{~cm}$ intra row spacing, respectively, of each harvestable row were also left as border effects. Moreover, the net harvestable area for broad casting method of planting was 5.5 by $4.5 \mathrm{~m}$. Five plants from the net plot area were pre tagged to collect data of plant height, pod number plant $^{-1}$ and three pods per each of these plants with a total of fifteen pods were considered to determine seed number pod $^{-1}$. Dry matter was measured using an electronic balance after the net plot area plants had been harvested and oven dried at $70^{\circ} \mathrm{C}$ until constant dry weight was attained. Similarly, shelled seed yield was weighed using electronic sensitive balance from the harvested plants of net plot area.

The collected agronomic data were subjected to the analysis of variance (ANOVA) using the SAS software computer package version 9.1 (SAS Institute, 2004) and significance difference among the treatment means was computed with least significant difference (LSD) at 5\% probability level (Gomez and Gomez, 1984).

\section{RESULTS AND DISCUSSION}

\section{Days to $90 \%$ physiological maturity}

Days to $90 \%$ physiological maturity did not differ due to planting spacing (Table 1). This lack of significance difference could be most probably due to less competitive effect of the associated Dekoko plants for limited growth resources until physiological maturity. Generally, it matured at a range of $79.67-81.33$ days starting from its planting time (Table 1). 
Table 1. Effect of planting spacing on mean values of days to $90 \%$ maturity and plant height of Dekoko.

\begin{tabular}{lcccccc}
\hline \multirow{2}{*}{ Treatments } & \multicolumn{3}{c}{ Days to $\mathbf{9 0 \%}$ maturity } & \multicolumn{3}{c}{ Plant height (cm) } \\
\cline { 2 - 7 } & $\mathbf{2 0 1 3}$ & $\mathbf{2 0 1 4}$ & Mean & $\mathbf{2 0 1 3}$ & $\mathbf{2 0 1 4}$ & Mean \\
\hline Broad casting & 80.67 & 80.00 & 80.33 & 40.33 & $44.33 \mathrm{e}$ & $42.33 \mathrm{~d}$ \\
$40 \times 10 \mathrm{~cm}$ & 80.33 & 80.00 & 80.17 & 41.00 & $47.73 \mathrm{de}$ & $44.37 \mathrm{~cd}$ \\
$50 \times 10 \mathrm{~cm}$ & 80.33 & 79.67 & 80.00 & 41.00 & $49.33 \mathrm{cde}$ & $45.17 \mathrm{bcd}$ \\
$60 \times 10 \mathrm{~cm}$ & 80.33 & 79.67 & 80.00 & 42.00 & $50.67 \mathrm{~cd}$ & $46.33 \mathrm{bcd}$ \\
$40 \times 15 \mathrm{~cm}$ & 80.33 & 80.00 & 80.17 & 41.67 & $54.67 \mathrm{ac}$ & $48.17 \mathrm{abc}$ \\
$50 \times 15 \mathrm{~cm}$ & 81.33 & 80.33 & 80.83 & 42.00 & $53.67 \mathrm{acd}$ & $47.83 \mathrm{abc}$ \\
$60 \times 15 \mathrm{~cm}$ & 82.00 & 80.33 & 81.17 & 42.67 & $56.00 \mathrm{a}$ & $49.33 \mathrm{ab}$ \\
$40 \times 20 \mathrm{~cm}$ & 80.33 & 80.00 & 80.17 & 43.67 & $54.67 \mathrm{ac}$ & $49.17 \mathrm{ab}$ \\
$50 \times 20 \mathrm{~cm}$ & 81.33 & 80.67 & 81.00 & 41.67 & $55.40 \mathrm{ac}$ & $48.53 \mathrm{abc}$ \\
$60 \times 20 \mathrm{~cm}$ & 81.00 & 80.33 & 80.67 & 42.00 & $59.27 \mathrm{a}$ & $50.63 \mathrm{a}$ \\
CV $(\%)$ & 1.59 & 0.76 & 1.00 & 8.58 & 6.91 & 5.17 \\
LSD $(0.05)$ & NS & NS & NS & NS & 6.23 & 4.18 \\
\hline
\end{tabular}

Means with the same letter $(s)$ in the same column are not significantly different at $P<0.05$; $N S=$ non-significant; $L S D=$ least significant difference; $C V=$ coefficient of variance.

\section{Plant height}

Plant height was not significantly affected by planting spacing in 2013 cropping season, but highly significantly varied $(P<0.01)$ in 2014 . In 2014 cropping season, the highest plant height $(59.27 \mathrm{~cm})$ was obtained from $60 \mathrm{x}$ $20 \mathrm{~cm}$, while the lowest $(44.33 \mathrm{~cm})$ was from broad casting method of planting. Similarly, the pooled mean result indicated that the greatest $(50.63 \mathrm{~cm})$ and least $(42.33 \mathrm{~cm})$ plant height was recorded from $60 \times 20 \mathrm{~cm}$ and broad casting methods, respectively. The greatest plant might be most probably due to availability of free access of environmental resources (water, nutrients and light) for the plants in the wider spacing. In line with this result, Shirtliffe and Johnston (2002) reported that plant height of different cultivars of field pea was significantly affected by row spacings. Similarly, Yayeh et al. (2014) showed that highest plant height for Sefinesh field pea variety was obtained under higher inters and intra row spacing. However, contrasting findings were achieved by Derya (2013) who indicated that denser plant population of pea increased plant height due to competition among plants.

\section{Number of pods plant ${ }^{-1}$}

Concerning pods plant ${ }^{-1}$, it was not significantly influenced due planting spacing in both cropping seasons. All the treatments were significantly at par. The pooled mean result, though non-significant, showed that slightly high number of pods (21.83) was obtained at spacing of $40 \mathrm{x}$ $15 \mathrm{~cm}$ while the lowest result (18.83) was gained from broad casting method of planting (Table 2). Number of pods plant $^{-1}$, an important primary yield component, ranged from 17.00 to 20.33 during 2013 and 19.00 to 23.67 during 2014 with maximum average pods plant ${ }^{-1}$ of 21.33. Yayeh et al. (2014) found that number of pods plant $^{-1}$ of field pea was not significantly affected by intra and inter row spacing, which was concurrent to the current finding. Similarly, in an experiment on peas, Biabani (2008) found that the effect of density on the pods plant ${ }^{-1}$ was not significant, while Biabani (2010) and Khandan et al. (2010) reported that influence of the density on the number of pods plant ${ }^{-1}$ was significant on chickpea

\section{Number of seeds pod $^{-1}$}

According to Table 2, spacing did not significantly affect the number of seeds pod $^{-1}$ of Dekoko in both seasons. The number of seeds pod $^{-1}$ of Dekoko ranged from 3.33 to 4.33. In agreement with this finding, Yayeh et al. (2014) reported that seeds pod ${ }^{-1}$ of field pea was not significantly influenced by planting spacing, and number of seeds pod $^{-1}$ ranged from 4.4 to 4.9 . Moreover, Ali et al. (2012) reported that, influence of plant density on number of grains pod $^{-1}$ of peas was non-significant, the grains pod $^{-1}$ ranged from 6.3 to 7.4 . This result also confirmed the findings of Derya (2013).

\section{Grain yield}

With respect to grain yield of Dekoko, it was highly significantly $(P<0.01)$ affected by planting spacing in both seasons. Accordingly, in 2013 cropping season, the highest grain yield $\left(549.90 \mathrm{~kg} \mathrm{ha}^{-1}\right)$ was obtained at a spacing of $40 \times 15 \mathrm{~cm}$, whereas the lowest numerical 
Table 2. Effect of planting spacing on mean values of pod number plant $^{-1}$ and seed number pod ${ }^{-1}$ of Dekoko.

\begin{tabular}{lcccccc}
\hline \multirow{2}{*}{ Treatments } & \multicolumn{3}{c}{ Pod number plant $^{-1}$} & \multicolumn{3}{c}{ Seed } \\
& $\mathbf{2 0 1 3}$ & $\mathbf{2 0 1 4}$ & Mean & $\mathbf{2 0 1 3}$ & $\mathbf{2 0 1 4}$ & Mean \\
\hline Broad casting & 18.67 & 19.00 & 18.83 & 4.00 & 3.33 & 3.67 \\
$40 \times 10 \mathrm{~cm}$ & 20.33 & 21.33 & 20.83 & 4.33 & 4.00 & 4.17 \\
$50 \times 10 \mathrm{~cm}$ & 17.33 & 21.67 & 19.50 & 3.67 & 4.00 & 3.67 \\
$60 \times 10 \mathrm{~cm}$ & 18.67 & 21.33 & 20.00 & 4.33 & 3.67 & 3.67 \\
$40 \times 15 \mathrm{~cm}$ & 20.00 & 23.67 & 21.83 & 3.67 & 4.33 & 4.33 \\
$50 \times 15 \mathrm{~cm}$ & 17.00 & 22.00 & 19.50 & 3.33 & 3.33 & 3.50 \\
$60 \times 15 \mathrm{~cm}$ & 20.00 & 20.33 & 20.17 & 3.67 & 4.33 & 3.83 \\
$40 \times 20 \mathrm{~cm}$ & 18.00 & 21.67 & 19.83 & 3.67 & 3.67 & 3.67 \\
$50 \times 20 \mathrm{~cm}$ & 18.67 & 21.33 & 20.00 & 3.67 & 4.00 & 3.83 \\
$60 \times 20 \mathrm{~cm}$ & 19.00 & 23.67 & 21.33 & 3.67 & 4.00 & 3.83 \\
CV $(\%)$ & 11.93 & 8.86 & 7.22 & 12.72 & 15.34 & 10.30 \\
LSD $(0.05)$ & $\mathrm{NS}$ & $\mathrm{NS}$ & $\mathrm{NS}$ & $\mathrm{NS}$ & $\mathrm{NS}$ & $\mathrm{NS}$ \\
\hline
\end{tabular}

$\mathrm{NS}=$ Non-significant; $\mathrm{LSD}=$ least significant difference $\mathrm{CV}=$ coefficient of variance.

Table 3. Mean values of grain and biomass yields of Dekoko as influenced by planting spacing.

\begin{tabular}{lcccccc}
\hline \multirow{2}{*}{ Treatments } & \multicolumn{3}{c}{ Grain yield $\left(\mathbf{k g ~ h a}^{-1}\right)$} & \multicolumn{3}{c}{${\text { Biomass yield }\left(\mathbf{k g ~ h a}^{-1}\right)}$} \\
\cline { 2 - 7 } & $\mathbf{2 0 1 3}$ & $\mathbf{2 0 1 4}$ & Mean & $\mathbf{2 0 1 3}$ & $\mathbf{2 0 1 4}$ & Mean \\
\hline Broad casting & $463.22 \mathrm{bcd}$ & $458.58 \mathrm{bcd}$ & $460.90 \mathrm{bcd}$ & $1420.97 \mathrm{acd}$ & $1405.04 \mathrm{bc}$ & $1413.00 \mathrm{bcd}$ \\
$40 \times 10 \mathrm{~cm}$ & $493.22 \mathrm{abc}$ & $514.48 \mathrm{ab}$ & $503.85 \mathrm{ab}$ & $1510.02 \mathrm{a}$ & $1474.17 \mathrm{ab}$ & $1492.10 \mathrm{ab}$ \\
$50 \times 10 \mathrm{~cm}$ & $502.18 \mathrm{ab}$ & $486.06 \mathrm{abc}$ & $494.12 \mathrm{bc}$ & $1445.65 \mathrm{ac}$ & $1437.12 \mathrm{ab}$ & $1441.39 \mathrm{bc}$ \\
$60 \times 10 \mathrm{~cm}$ & $456.22 \mathrm{bcd}$ & $447.98 \mathrm{~cd}$ & $452.10 \mathrm{~cd}$ & $1429.56 \mathrm{ac}$ & $1386.56 \mathrm{bc}$ & $1408.06 \mathrm{bcd}$ \\
$40 \times 15 \mathrm{~cm}$ & $549.90 \mathrm{a}$ & $539.25 \mathrm{a}$ & $544.58 \mathrm{a}$ & $1576.11 \mathrm{a}$ & $1549.18 \mathrm{a}$ & $1562.65 \mathrm{a}$ \\
$50 \times 15 \mathrm{~cm}$ & $457.33 \mathrm{bcd}$ & $448.61 \mathrm{~cd}$ & $452.97 \mathrm{~cd}$ & $1384.21 \mathrm{cde}$ & $1372.70 \mathrm{bc}$ & $1378.46 \mathrm{cde}$ \\
$60 \times 15 \mathrm{~cm}$ & $434.94 \mathrm{~d}$ & $419.08 \mathrm{~d}$ & $427.01 \mathrm{~d}$ & $1339.23 \mathrm{cde}$ & $1335.19 \mathrm{c}$ & $1337.21 \mathrm{cde}$ \\
$40 \times 20 \mathrm{~cm}$ & $482.11 \mathrm{bcd}$ & $434.41 \mathrm{~cd}$ & $458.26 \mathrm{~cd}$ & $1366.29 \mathrm{cde}$ & $1324.39 \mathrm{c}$ & $1345.34 \mathrm{cde}$ \\
$50 \times 20 \mathrm{~cm}$ & $442.00 \mathrm{~cd}$ & $416.11 \mathrm{~d}$ & $429.06 \mathrm{~d}$ & $1263.41 \mathrm{de}$ & $1349.29 \mathrm{bc}$ & $1306.35 \mathrm{de}$ \\
$60 \times 20 \mathrm{~cm}$ & $426.23 \mathrm{~d}$ & $409.38 \mathrm{~d}$ & $417.81 \mathrm{~d}$ & $1243.85 \mathrm{e}$ & $1307.30 \mathrm{c}$ & $1275.57 \mathrm{e}$ \\
$\mathrm{CV}(\%)$ & 7.03 & 7.72 & 5.51 & 6.77 & 5.60 & 4.70 \\
$\mathrm{LSD}(0.05)$ & 56.77 & 60.55 & 43.88 & 162.33 & 133.87 & 112.66 \\
\hline
\end{tabular}

Means with the same letter(s) in the same column are not significantly different at $\mathrm{P}<0.05$; $L S D=$ least significant difference; $\mathrm{CV}=$ coefficient of variance.

result $\left(426.23 \mathrm{~kg} \mathrm{ha}^{-1}\right)$ was recorded from a spacing of 60 $x 20 \mathrm{~cm}$ (Table 3). A similar result was also obtained in 2014. With reference to Table 3 , the highest grain yield was produced at a spacing of $40 \times 15 \mathrm{~cm}$ where it gave $31.72 \%$ yield advantage over $60 \times 20 \mathrm{~cm}$ spacing. Moreover, the pooled mean result indicated that planting spacing of $40 \times 15 \mathrm{~cm}$ produced the highest yield of Dekoko. The lowest grain yield production could be due to extreme wider spacing at which the required population density ha ${ }^{-1}$ could not be accommodated and this in turn results in production of low grain yield because of minimum population density. This confirmed the previous findings of Yayeh et al. (2014) who showed that further increase in intra and inter row spacing together for small seeded field pea cultivars (Megeri) result in yield penalty. Likewise, Ali et al. (2012) and Derya (2013) found that seed yield of field pea was significantly affected due population density.

\section{Biomass yield}

Like grain yield, biomass yield was significantly influenced $(\mathrm{P}<0.05)$ by planting spacing in both seasons (Table 3 ). In 2013, the highest biomass yield (1576.11 kg ha ${ }^{-1}$ ) was produced at a spacing of $40 \times 15 \mathrm{~cm}$ which gave $26.73 \%$ more biomass yield than $60 \times 20 \mathrm{~cm}$ at which the lowest result was obtained. Correspondingly, in 2014, $40 \times 15$ 
$\mathrm{cm}$, which gave the highest biomass yield, was statistically at par with $40 \times 10$ and $50 \times 10 \mathrm{~cm}$. Nevertheless, the lowest value $\left(1307.30 \mathrm{~kg} \mathrm{ha}^{-1}\right)$ was obtained from $60 \times 20 \mathrm{~cm}$ which was $15.61 \%$ lower than the biomass yield of $40 \times 15 \mathrm{~cm}$. In addition, the pooled mean result revealed that the maximum yield was observed at spacing of $40 \times 15 \mathrm{~cm}$, while the minimum was from $60 \times 20 \mathrm{~cm}$. This could be attributed to sparse density of plants in wider spacing to have appropriate density and which resulted in low biomass yield. This result is consistent with the work of Ali et al. (2012) who reported that biological yield of peas was significantly affected by plant density where the highest density was obtained from 70 plants $\mathrm{m}^{2}$.

\section{Conclusions}

Optimum planting spacing has a promising impact in improving the productivity of Dekoko. According to the results of this experiment, plant height, grain yield and biomass yield were significantly affected by planting spacing of Dekoko. The greatest plant height was obtained at a spacing of $60 \times 20 \mathrm{~cm}$. Moreover, the maximum grain and biomass yields were obtained at spacing of $40 \times 15 \mathrm{~cm}$ in both cropping seasons as compared to the other treatments. It is, therefore, concluded that planting spacing of $40 \times 15 \mathrm{~cm}$ can be recommended for the growers in the study area to improve Dekoko productivity. Moreover, it can be recommended from the findings that further investigation on different varieties together with different fertilizer levels, soil types, utilization and quality aspects, can be a step forward to identify best technology on the growth and yield improvements of Dekoko.

\section{Conflict of interest}

The authors have not declared any conflict of interest

\section{ACKNOWLEDGEMENTS}

The authors are thankful to the Ethiopian Institute of Agricultural Research (EIAR) for funding this research project. The authors also sincerely acknowledge the Mehoni Agricultural Research Center for providing all the farm facilities.

\section{REFERENCES}

Ali R, Mohammad-Eghbal G, Mokhtar G (2012). Effect of supplemental irrigation and plant density on yield and yield components of peas (Pisum sativum L.) in Kermanshah region. Afr. J. Agric. Res. 7(15):2353-2358
Biabani A (2008). Effect of planting patterns (row spacing and plant in row) on the green yield pea garden (Pisum sativum var. shamshiri). J. Agric. Sci. Nat. Resour. 15(5):39-43.

Biabani A (2010). The effect of planting arrangements on yield, yield components and some agronomic characteristics in chickpea. EJCP 2(2): $15-24$

Derya OY (2013). Impact of plant density on yield and yield components of pea (Pisum sativum ssp. sativum L.) cultivars. ARPN J. Agric. Biol. Sci. 2(8):169-174.

Felton WL, Marcellos H, Murison RD (1996). The effect of row spacing and seeding rate on chickpea yield in Northern New South Wales. Proc. $8^{\text {th }}$ Aust. Agron. Conf. Toowoomba. pp. 251-253.

Gan Y, Gossen BD, Li L, Ford F, Banniza S (2007). Cultivar type, plant population and ascochyta blight in chickpea. Agron. J. 99:1463-1470.

Gan YT, Miller PR, McConkey BG, Zertner RP, Liu PH, McDonald CL (2003). Optimum plant population density for chickpea and dry pea in a semiarid Environment. Can. J. Plant Sci. 83:1-9.

Gomez KA, Gomez AA (1984). Statistical procedures for agricultural research, $2^{\text {nd }}$ edition. John Wiley and Sons Inc., New York.

Haddis Y, Hussein M, Berhanu A, Birhanu A (2015). Association of traits with yield in Dekoko (Pisum sativum var. abyssinicum) accessions in the highlands of southern Tigray, Ethiopia. Afr. J. Agric. Res. 10(12):1480-1487.

Haileslassie G, Haile A, Wakuma B, Kedir J (2015). Performance evaluation of hot pepper (Capsicum annum L.) varieties for productivity under irrigation at Raya Valley, Northern, Ethiopia. Basic Res. J. Agric. Sci. Rev. 4(7):211-216

Kakiuchi J, Kobata T (2004). Shading and thinning effects on seed and shoot dry matter increase in determinate soybean during the seed filling period. Agron. J. 96:398-405.

Khandan Bejandi T, Seyed Sharifi R, Sedghi M, Asgari Zakaria R, Namvar A, Jafari Moghadam M (2010). Effect of plant density, rhizobia and microelements on yield and some of physiological characteristics of pea. EJCP 3(1):139-157.

Mohammed JR, Shamsuddin T, Mushtaque AR, Fazel KR (1984). Effects of Row and Plant Spacing on Yield and Yield Components of Soybean. Pak. J. Agric. Res. 5(2):83-87.

Nawaz M, Hussain A, Chaudhary FM, Maqsood M, Azam M (1995). Effect of sowing date and plant population on seed yield and yield components of chickpea. J. Agric. Res. 33(5):317-328.

Parihar SS (1996). The effect of row and plant spacing on the growth and yield of chickpea. Indian J. Agron. 41(4):604-607.

Pawar SU, Kharwade ML, Awari HW (2007). Effect of plant density on vegetative growth and yield performance of different varieties of french bean under irrigated condition. J. Agric. Sci. 20(3):684-685.

Samih A (2008). Effect of plant density on flowering date, yield and quality attribute of bush beans (Phaseolus vulgaris L.) under center pivot irrigation system. Am. J. Agric. Biol. Sci. 3(4):666-668.

SAS (Statistical Analysis System) Institute (2004). SAS user guides, version 9.1. SAS Inc. Cary. North Carolina, USA.

Sentayehu A (2009). Assessment of nutrient contents of different field pea genotypes (Pisium sativum L.) in south west Ethiopia. Department of plant sciences, Jima University, Jimma, Ethiopia.

Shirtliffe SJ, Johnston AM (2002). Yield-density relationships and optimum plant populations in two cultivars of solid-seeded dry bean (Phaseolus vulgaris L.) Grown in Saskatchewan. Can. J. Plant Sci. 82:521-529.

Yayeh B, Fekremariam A, Oumer B (2014). Effect of plant spacing on the yield and yield component offield pea (Pisum sativum L.) at Adet, North Western Ethiopia. Agric. For. Fish. 3(5):368-373.

Yemane A, Skjelvag AO (2002). The physico-chemical features of dekoko (Pisum sativum var. abyssinicum) seeds. J. Agron. Crop Sci. 189:14-22. 